\title{
Do luto à luta: um estudo sobre a Comissão de Familiares de Mortos e Desaparecidos Políticos no Brasil ${ }^{1}$
}

Carlos Artur Gallo*

Resumo: Analisam-se as formas como os familiares de pessoas mortas e desaparecidas durante a ditadura civil-militar no Brasil (1964-1985) se organizaram para reivindicar: 1) o reconhecimento da responsabilidade do Estado brasileiro pelas violações aos direitos humanos praticadas; 2) a apuração das reais circunstâncias em que estas mortes e desaparecimentos ocorreram; 3) a responsabilização dos culpados; 4) o resgate e a preservação da memória relativa a estes fatos. Fortalecida na primeira metade da década de 1970, a luta dos familiares organizados em torno da Comissão de Familiares de Mortos e Desaparecidos Políticos (CFMDP) estende-se até a atualidade. Em mais de três décadas, a CFMDP trabalha de forma insistente junto à sociedade na tentativa de fazer com que os crimes ocorridos não sejam esquecidos e buscando ampliar seu apoio com vistas à construção de políticas que atendam suas demandas. Apesar das conquistas obtidas, a CFMDP ainda lida com legados do autoritarismo que limitam visivelmente a obtenção de avanços significativos para a causa.

Palavras-chave: Comissão de Familiares de Mortos e Desaparecidos Políticos. Direitos Humanos. Ditadura Civil-Militar no Brasil (1964-1985). Legados Autoritários. Memória da Repressão Política.

* Doutorando em Ciência Política (UFRGS). Bolsista da CAPES.

E-mail: galloadv@gmail.com 
DO LUTO À LUTA: um estudo sobre a Comissão de Familiares...

\section{Introdução}

Na década de 1960, auge da Guerra Fria, o temor - por parte dos norte-americanos - de que fossem instalados novos regimes de caráter socialista a exemplo de Cuba, tensionou a política externa regional, repercutindo na política interna de diversos países latinoamericanos (MOTTA, 2002, p. 231-233). Dentre esses países que sofreram a segunda onda reversa de democratização (HUNTINGTON, 1994, p. 28-29), encontra-se o Brasil, onde, em 1964, houve um golpe de Estado que deu início a uma ditadura civil-militar que perdurou até 1985 . Os militares brasileiros no poder, apoiados pelas elites, promoveram, com o endurecimento das políticas de Estado e a neutralização dos opositores, o alinhamento do modelo econômico interno aos novos padrões de expansão do capitalismo (MARTINS, 1988, p. 114-116).

Baseada na Doutrina de Segurança Nacional (DSN), a neutralização dos opositores era obtida mediante exílio, banimento, perseguição, prisão, julgamento, tortura e, nos casos extremos, com a eliminação de militantes comunistas ou classificados como de esquerda. Visto que (segundo esta doutrina) todos indivíduos que se opunham ao regime eram inimigos internos declarados, e, em sentido amplo, todos os cidadãos eram inimigos internos em potencial, é um equívoco afirmar que o uso da violência política era exceção, quando, na verdade, a sua prática era condição à uniformizaçãoformação de uma sociedade política passiva a serviço da DSN e dos militares-ditadores no poder (PADRÓS, 2006; 2008).

No governo do ditador-presidente Ernesto Geisel (1974-1979), começa, no interior do próprio regime, a preparação da retirada dos militares do poder, com a execução de um projeto de distensão lenta, gradual e segura. Excepcionalmente controlado pelos militares no poder, a liberalização no Brasil resguardou-lhes "prerrogativas políticas extraordinárias" (ARTURI, 2001, p. 12). Tais prerrogativas garantiram que, além da manutenção dos militares como um ator político informal relevante pós-liberalização, os agentes da repressão política restassem imunizados de responsabilização pelas violações cometidas, valendo-se de uma interpretação abrangente da Lei da Anistia (Lei no 6.683 de 1979) que sedimentou no imaginário 
popular a ideia de que a anistia foi recíproca e, beneficiando tanto aos torturados quanto aos torturadores, tudo o que passou deveria ser esquecido (MEZAROBBA, 2003).

Entre avanços e retrocessos, o tema referente à responsabilização dos repressores pelas reiteradas violações aos direitos humanos cometidas no período, bem como as discussões sobre o que se fez da memória da repressão, tem sido com frequência reinseridos na pauta das discussões políticas do país. Apesar disso, quando fala-se da memória da repressão, segue-se abordando um tema essencialmente delicado, sendo que, no que tange à apropriação do tema pelos acadêmicos em geral, vê-se que é somente nos últimos anos que o interesse pelo mesmo foi ampliado na agenda de pesquisas (REIS; RIDENTI; MOT'TA, 2004, p. 9-11). Tendo este contexto como ponto de partida, o presente estudo toma como objeto de análise uma luta que, contra o esquecimento, vem sendo travada pelos integrantes da Comissão de Familiares de Mortos e Desaparecidos Políticos (CFMDP). O estudo pretende responder, basicamente: Como foi formada a CFMDP? Que estratégias e ações integraram sua luta? Como ela conseguiu dar visibilidade à questão? Quais os limites e quais os avanços obtidos ao longo da sua trajetória?

O objetivo geral foi analisar a trajetória da CFMDP desde a sua formação, na década de 1970, até a atualidade. Como objetivos específicos, foi proposto: 1) analisar o contexto em que se deu o surgimento das demandas dos familiares e em que foi criada a Comissão; 2) analisar a forma como a mesma se organiza após o fim do período autoritário; 3) apreender o conteúdo das suas demandas; 4) identificar a forma como a questão dos mortos e desaparecidos foi trabalhada ao longo dos anos; 5) identificar quais são os limites que se apresenta$\mathrm{ram} /$ apresentam às demandas dos familiares durante a sua trajetória.

No que se relaciona à metodologia utilizada, fez-se uso de metodologia de pesquisa essencialmente qualitativa. Inicialmente, foi realizada pesquisa bibliográfica sobre o tema, valendo-se, além da produção acadêmica sobre os mortos e desaparecidos políticos no Brasil e demais regimes autoritários, da análise de dados obtidos em documentos produzidos pela Comissão e por outros grupos de defesa dos direitos humanos, e, ainda, por órgãos vinculados ao Governo Federal. Posteriormente, os dados obtidos com a pesquisa 
DO LUTO À LUTA: um estudo sobre a Comissão de Familiares...

bibliográfica foram complementados mediante entrevista aberta com representante da CFMDP.

No tocante à estrutura da exposição, a mesma encontra-se dividida em três partes. Na primeira delas, resgata-se a história da CFMDP, desde o seu surgimento, nos anos 70, até a edição da Lei $\mathrm{n}^{\circ} 9.140 / 95$. Na sequência, abordam-se os principais fatos da trajetória da Comissão, desde a edição da Lei até a atualidade. Na última seção, analisa-se a atuação da CFMDP à luz de legados autoritários existentes no cenário político brasileiro.

\section{A luta dos familiares de mortos e desaparecidos no Brasil}

A partir das ditaduras de Segurança Nacional no Cone Sul, muitos indivíduos considerados inimigos do Estado de acordo com a DSN foram perseguidos, presos e torturados, sendo, em casos extremos, mortos ou desaparecidos pela repressão (AMNISTÍA INTERNACIONAL, 1983; 1993; ARQUIDIOCESE DE SÃO PAULO, 1985) ${ }^{2}$.

Os efeitos das mortes e dos desaparecimentos, entretanto, projetam-se para além do preso, para além do torturado, para além do morto e para além do desaparecido, transmitindo-se para suas famílias e para seus amigos, que, além de terem seu luto negado ou dificultado pelo aparato repressivo, passam a conviver com a incerteza - psicologicamente torturante - do destino reservado aos seus entes queridos (ONU, 1993, p. 1-2), mas também para a coletividade política, que tem sua história adulterada (TELES, 2007; 2009a; 2009b; 2010). De acordo com Ludmila da Silva Catela (2001, p. 159), "[...] a ausência de um túmulo provoca a necessidade de reinventar novas formas e estratégias para lembrar os desaparecidos. Essas estratégias podem ser privadas ou públicas, individuais ou coletivas".

No que se relaciona ao caso brasileiro, a reinvenção das estratégias de fortalecimento da memória em detrimento do esquecimento expressa na luta dos familiares de mortos e desaparecidos políticos ${ }^{3}$ origina-se de forma quase que instintiva, no exato momento em que: a) não se tinha quaisquer notícias de um familiar-militante, 
e, ao procurar-se informações nos órgãos de Segurança, ocorria a negativa da sua detenção; b) se tomava conhecimento da morte do familiar ausente através de versões oficiais permeadas por circunstâncias obscuras. É com a intensificação da organização dos familiares na primeira metade da década de 1970, porém, que este drama inicialmente restrito ao espaço privado das famílias começa a ser lançado para o espaço público (ALMEIDA et al., 2009, p. 21-23; ALMEIDA TELES, 2001, p. 157-160).

Naquele momento, apesar das dificuldades de veiculação de notícias sobre o tema, devido à censura (BRASIL, 2010, p. 61), apoiados por integrantes da Igreja Católica paulista, foram organizadas várias manifestações públicas de repúdio à repressão e ao regime nas missas rezadas na Catedral da Sé por Dom Paulo Evaristo Arns, em memória de Luiz Eduardo Rocha Merlino, em 1971, de Alexandre Vannucchi Leme, em 1973, de Vladimir Herzog, em 1975 e de Manoel Fiel Filho, em 1976 - todos mortos sob tortura (ALMEIDA et al., 2009, p. 298). Dom Paulo, além de auxiliar os familiares realizando as missas, obtinha suporte jurídico oferecido por integrantes da Comissão Justiça e Paz de São Paulo (CJP-SP), criada por ele em 1972, e participando pessoalmente (com familiares), em audiência ocorrida em 1974, com o Chefe da Casa Civil do Governo Geisel, Golbery do Couto e Silva, na qual se pedia informações sobre o desaparecimento de 22 militantes (ALMEIDA et al., 2009, p. 628).

Ao mesmo tempo em que a mobilização, divulgação e o respaldo à causa cresciam, sob a proteção de Dom Paulo, outras fontes de apoio, como a ala progressista do Movimento Democrático Brasileiro (MDB), iam sendo obtidas (ALMEIDA et al., 2009, p. 699; BRASIL, 2010, p. 60-63). Com o início da distensão, na esteira do apoio à causa geral dos direitos humanos, ofereceram solidariedade e respaldo institucional aos familiares membros da Ordem dos Advogados do Brasil (OAB), da Associação Brasileira de Imprensa (ABI) e da Sociedade Brasileira para o Progresso da Ciência (SBPC) (CARVALHO, 2010, p. 185-188). No âmbito internacional, a questão foi reiteradamente trabalhada, ocorrendo a publicação de denúncias e a realização de mobilizações promovidas por organizações como a Anistia Internacional, que pugnava pelo fim das violações no país (BRASIL, 2010, p. 58-62). 
DO LUTO À LUTA: um estudo sobre a Comissão de Familiares...

Com o passar do tempo, as mobilizações dos familiares, que até então produziam resultados de baixa intensidade, mas serviam como mecanismo de pressão, encontraram na luta pela Anistia espaço para amadurecer e reelaborar suas estratégias (MARTINS, 1978, p. 119-155). Assim, na vigência dos trabalhos dos Comitês Brasileiros pela Anistia (CBA's), criados entre 1978 e 1979, os familiares integraram-se à campanha reivindicando: 1) a elucidação das circunstâncias das mortes e dos desaparecimentos; 2) a localização dos corpos; 3) a punição dos envolvidos (ALMEIDA TELES, 2009, p. 162-163).

$\mathrm{Na}$ mesma época, ao divulgarem as primeiras listas de mortos e desaparecidos, os familiares enfrentaram ataques diretos de setores governistas ou de seus apoiadores, que, na tentativa de deslegitimar suas demandas, apresentavam falsas informações sobre o paradeiro dos desaparecidos, dando a entender que haviam fugido do país e viviam com identidade falsa no exterior (BRASIL, 2010, p. 62-63; MEZAROBBA, 2003, p. 64-65). Paralelamente, também ocorria a divulgação de boatos diretamente às famílias (BRASIL, 2010, p. 68-69).

Para frustração dos familiares, o trabalho realizado nos anos 1970 e canalizado para o CBA foi insuficiente para fazer com que a Lei da Anistia atendesse às suas demandas; afinal, a única alternativa que a Lei $\mathrm{n}^{\circ} 6.683$ oferecera era a emissão de atestados de paradeiro ignorado ou de morte presumida para os desaparecidos. Em meio às comemorações organizadas pela volta dos exilados e pela libertação de muitos dos presos políticos, a dor das famílias que continuavam com seus mortos insepultos ou com suas histórias obscurecidas por mortes ocorridas em circunstâncias não esclarecidas foi sufocada.

Assim, a partir de agosto de 1979, os familiares que haviam compartilhado da luta pela Anistia com outros setores da sociedade passaram a trabalhar sua demanda específica de forma fragmentada, uma vez que o CBA deixara de existir. Ao falar sobre o período, Suzana Keniger Lisbôa ${ }^{4}$ refere que:

[...] o impacto da lei na causa dos familiares, da Lei da Anistia, foi muito forte. [...] muita gente se desmobilizou com a anistia. [...] Nós nos sentimos muito abandonados na época.

Anos 90, Porto Alegre, v. 19, n. 35, p. 329-361, jul. 2012 
Ali que a gente começou, eu acho, a se manifestar enquanto Comissão de Familiares, a gente botava "do CBA", depois o CBA deixou de existir, nós começamos a adotar esse nome $e^{5}$.

Por essa razão, os familiares, impactados pela Anistia, reestruturaram-se. Enfrentando inicialmente a desmobilização de alguns membros e a migração de outros para entidades como os Grupos Tortura Nunca Mais, surgidos na década de 1980, no Rio de Janeiro, em São Paulo, Belo Horizonte e Recife, coube aos integrantes engajados na manutenção da CFMDP, na época melhor estruturada em São Paulo, delimitar a causa no novo cenário político.

Nessa fase, antes de consolidar a Comissão, Suzana Lisbôa ${ }^{6}$ relata que os familiares tentaram organizar uma entidade nacional chamada ABRAFAM (Associação Brasileira dos Familiares de Mortos e Desaparecidos), pretendendo articulá-la junto à FEDEFAM (Federación Latinoamericana de Asociaciones de Familiares de Detenidos-Desaparecidos) ${ }^{7}$. Apesar de a ABRAFAM não ser criada, mantendo-se a Comissão saída dos CBA's como instância centralizadora da causa dos familiares, Suzana refere que o contato com famílias de desaparecidos na Argentina, em 1984, no $1^{\circ}$ Congresso da FEDEFAM, deu novo fôlego aos familiares no Brasil. Isso porque, ao verem que organizações criadas na Argentina - Madres e Abuelas da Plaza de Mayo - não aceitavam as mortes de seus familiares, requeriam sua aparição com vida e desvinculavam o caráter político das detenções e desaparecimentos, membros da CFMDP sentiram-se "[...] mil anos luz a frente deles"

Além disso, após agosto de 1979, familiares deram continuidade à causa realizando outras atividades que dessem mais visibilidade ao tema pela população. Este foi o caso da exibição, em escolas paulistas, de material audiovisual sobre os casos de mortes e desaparecimentos praticados na América Latina, bem como das tentativas de que anualmente, no final de maio, fossem realizadas atividades alusivas à passagem de uma semana mundial dedicada à memória dos desaparecidos. Num outro sentido, a memória da repressão foi trabalhada, também, nos momentos em que se deram os primeiros traslados de corpos de militantes. Em 1982, por exemplo, os restos mortais de Luiz Eurico Tejera Lisbôa foram trasladados para Porto 
DO LUTO À LUTA: um estudo sobre a Comissão de Familiares...

Alegre, onde foram velados na Assembleia Legislativa do Estado do Rio Grande do Sul, com o apoio da Comissão de Cidadania e Direitos Humanos?.

Igualmente, foi no final de 1979 que a CFMDP deu andamento à elaboração de listas com os nomes das vítimas. Para a elaboração destas primeiras listagens, foi preciso lidar, por exemplo, com divergências de alguns familiares. No tocante a estas divergências internas à Comissão, Suzana ${ }^{10}$ recorda que, sobretudo famílias de militantes do PCB e do PCdoB, queriam fazer listagens de acordo com a organização dos militantes. Como resultado destes trabalhos, a CFMDP conseguiu, em novembro de 1979, fazer a primeira versão do seu relatório de casos de mortes e desaparecimentos, apresentando-o em evento realizado pelos CBA's em Salvador, para discutir a Anistia (ALMEIDA et al., 2009, p. 19-20).

Em outra direção, familiares trabalharam também com vistas ao resgate dos desaparecidos do Araguaia. Com este objetivo, em 1980 foi organizada a primeira caravana de familiares de 22 desaparecidos à região da Guerrilha do Araguaia, contando-se com grande apoio da Igreja Católica (BRASIL, 2010, p. 64). Ao retornarem, familiares dirigiram-se para Brasília, onde relataram os trabalhos realizados na região e solicitaram que o Governo se manifestasse sobre a repressão. Os resultados práticos, contudo, foram limitados, visto que o Governo não atendeu às solicitações dos familiares, tendo servido esses levantamentos como ponto de partida para a realização de novas buscas (ALMEIDA et al., 2009, p. 721).

Em maio de 1983, familiares de mortos e desaparecidos e a CJP-SP organizaram, no Teatro Municipal de São Paulo, o Tribunal Tiradentes. Presididio por Teotônio Vilela ${ }^{11}$, fez o julgamento público da Lei de Segurança Nacional, pugnou pela sua revogação e promoveu a denúncia e o debate públicos das violações pós-1964 (ALMEIDA et al., 2009, p. 604, p. 719). Além de medidas simbólicas, passos significativos na busca dos desaparecidos e dos mortos sepultados com nomes falsos em valas comuns foram dados em 1990, com a abertura da vala clandestina (Vala de Perus) do Cemitério Dom Bosco, de Perus, na periferia de São Paulo (ALMEIDA et al., 2009, p. 25-26; BRASIL, 2010, p. 124-133). 
Essa vala clandestina foi descoberta na década de 1970, quando familliares obtiveram informações, de trabalhadores do local, de que agentes da repressão utilizaram o cemitério para sepultar (com nomes falsos) suas vítimas, e que, em 1975, mais de 1000 ossadas haviam sido exumadas e realocadas para uma vala aberta clandestinamente. Apesar de saberem da sua existência, tendo denunciado o encontro da sepultura de Luiz Eurico Tejera Lisbôa neste cemitério durante a votação da Lei da Anistia, não havia na época condições de promover uma investigação (ALMEIDA et al., 2009, p. 723; BRASIL, 2010, p. 124).

O momento propício para concretizar essa intenção ocorreria quando, redescoberta acidentalmente pelo repórter Caco Barcellos durante uma pesquisa sobre violência policial a partir de 1970, o repórter da Rede Globo encontrou indícios dos sepultamentos clandestinos, e, ao divulgá-los, desencadeou grande repercussão no país (BRASIL, 2010, p. 124). Com o auxílio de Suzana Lisbôa, Caco Barcellos cruzou dados do IML de São Paulo com os livros de registro do cemitério sendo encontrados indícios de que no mínimo 30 corpos de militantes mortos ou desaparecidos estariam no local (BRASIL, 2010, p. 125).

Como consequência, membros da CFMDP obtiveram o apoio de Luiza Erundina, prefeita de São Paulo, para investigar o caso. Assim, foi criada a Comissão Especial de Investigação das Ossadas de Perus (CEIOP) e instaurada, de outubro de 1990 a maio de 1991, uma CPI na Câmara Municipal. As investigações estenderam-se para outros cemitérios de São Paulo, estimulando levantamentos em outras cidades. Como resultado, identificou-se 4 cemitérios em São Paulo, 6 no Rio de Janeiro, 3 em Pernambuco, 1 no Paraná, 4 em Tocantins, 1 em Minas Gerais e 1 no Araguaia, em Xambioá (BRASIL, 2010, p. 125-133).

Além disso, a CPI e a CEIOP tornaram possível a retirada de ossadas da Vala de Perus - e de outras valas - e a sua transferência, para fins de catalogação e futura identificação, para o Departamento Médico Legal da Universidade Estadual de Campinas (DML/UNICAMP) (ALMEIDA; et al., 2009, p. 25). Com a posse de Paulo Maluf, em 1993, a identificação dos restos mortais tornou-se um capítulo a parte na luta da CFMDP, pois o apoio da Prefeitura, ocupada pelo mesmo 
DO LUTO À LUTA: um estudo sobre a Comissão de Familiares...

político que ocupara o cargo quando foi construído o cemitério, cessou (ALMEIDA et al., 2009, p. 26; BRASIL, 2010, p. 126).

\section{A atuação da CFMDP a partir da lei no 9.140 de 1995}

Se o contexto político nacional da primeira metade dos anos de 1990 parecia maduro para tratar a questão dos mortos e desaparecidos, sobretudo diante do realinhamento das agendas nacional e internacional de proteção aos direitos humanos que estava sendo consolidado no país (KOERNER, 2003), é fato que continuavam presentes opiniões semelhantes às que haviam justificado o endurecimento da repressão e deslegitimado as demandas da CFMDP. Apesar de permanecerem mesmo em ambiente democrático, a CFMDP lançou o germe da Lei no 9.140 em 1993, com a realização de um encontro com vistas à elaboração um Projeto de Lei (PL) pelo Governo Federal.

No encontro, contando com o auxílio dos Grupos Tortura Nunca Mais, da Anistia Internacional e da Human Rights Watch, dentre outros, familiares elaboraram uma proposta que, entregue ao Ministro da Justiça, seria encaminhada ao Congresso pelo presidente Itamar Franco. Diante da frustração causada pelo presidente, que, mesmo após as vigílias realizadas no Rio de Janeiro, em Brasília, Porto Alegre e Recife requerendo a elaboração do PL, não deu andamentos à questão, os familiares rearticularam-se, e, em 1994, fizeram com que uma Carta Compromisso com os pontos apresentados ao Ministro da Justiça fosse assinada por representantes de Fernando Henrique Cardoso (FHC) e Luís Inácio Lula da Silva, principais candidatos à Presidência (ALMEIDA et al., 2009, p. 3233; BRASIL, 2007, p. 30-33).

Com a eleição e a posse, em 1995, do presidente FHC - ele próprio uma vítima da ditadura -, a CFMDP renovou suas expectativas. Ter assinado a Carta Compromisso, no entanto, não bastou para que ela fosse cumprida, sendo determinante, além da contínua pressão dos familiares, três fatos ocorridos no primeiro semestre do seu mandato. Em abril, Pierre Sané, Secretário Geral da Anistia Internacional, cobrou pessoalmente de FHC uma solução, sendo que, 
após este encontro, Sané criticou o presidente por não estar engajado na solução da questão e na punição das violações aos direitos humanos praticadas, que, conforme ele frisara, são imprescritíveis. No mês de maio, diante da imprensa internacional, FHC foi interpelado (em Washington) por Ângela Harkavy, irmã do desaparecido político Pedro Alexandrino de Oliveira Filho, que cobrou do presidente informações a respeito do paradeiro do irmão. Finalmente, e ainda no mês de maio, o jornal inglês The Guardian denunciou que um ex-torturador era adido militar da Embaixada do Brasil em Londres (ALMEIDA et al., 2009, p. 32-33, p. 591; BRASIL, 2007, p. 32; MEZAROBBA, 2003, p. 83).

Diante desses acontecimentos, em junho de 1995, o presidente FHC incumbiu Nelson Jobim, à época Ministro da Justiça, de dar andamentos à questão, sendo redigido o PL n ${ }^{\circ}$ 869/95. Contando-se com a participação da CFMDP e de integrantes de outros organismos de proteção aos direitos humanos, o PL foi encaminhado para apreciação no Congresso Nacional, e, havendo pouco debate por tramitar com urgência urgentíssima, e, sem nenhuma emenda, o texto foi sancionado por FHC em 4 de dezembro de 1995, dando origem à Lei no 9.140 (ALMEIDA et al., 2009, p. 33; BRASIL, 2007, p. 33-37).

Durante a confecção da Lei, entretanto, foi preciso apaziguar os ânimos dos militares, e, mesmo estabelecendo desde o início das discussões que os limites da Lei a ser criada seriam pautados pela interpretação da anistia recíproca, “[...] o assunto ainda era considerado tabu entre alguns círculos militares” (BRASIL, 2007, p. 36). Por isso, o próprio presidente, acompanhado pelo Ministro da Justiça, reuniu-se com representantes das Forças Armadas para garantir que a proposta não era revanchista (BRASIL, 2007, p. 3637). Mesmo assim, pouco antes da aprovação da redação final do PL $\mathrm{n}^{\mathrm{o}} 869 / 95$, o Deputado Jair Bolsonaro ${ }^{12}$, com apoio de integrantes das Forças Armadas, ventilou na Câmara a ideia de indenizar familiares de militares que morreram no combate à guerra interna (PRADO, 2004, p. 88-89).

De qualquer forma, da aprovação da Lei dos Mortos e Desaparecidos decorreu: a) o reconhecimento da responsabilidade do Estado brasileiro pelas mortes e pelos desaparecimentos de 136 pessoas listadas como desaparecidas políticas no Anexo I da Lei; b) 
DO LUTO À LUTA: um estudo sobre a Comissão de Familiares...

a garantia de que as famílias das pessoas listadas no Anexo poderiam registrar seus óbitos; c) a criação da Comissão Especial sobre Mortos e Desaparecidos Políticos (CEMDP), para concessão de indenização pecuniária aos familiares das pessoas listadas na Lei; d) a possibilidade de serem julgados novos casos ocorridos entre 1961 e 1979 (conforme o lapso temporal que havia sido previsto na Lei da Anistia), concedendo-lhes as respectivas indenizações; e) a fixação de um valor mínimo $(\mathrm{R} \$ 100.000,00)$ para as indenizações; f) a prerrogativa de a CEMDP requerer de órgãos oficiais a apresentação dos documentos convenientes à análise dos pedidos.

Ainda que a Lei tenha possibilitado inegáveis avanços para o tratamento da questão, a CFMDP destaca os seguintes problemas decorrentes da sua aprovação (ALMEIDA et al., 2009, p. 33-34): 1) eximiu o Estado de identificar e responsabilizar os agentes envolvidos nos crimes ocorridos durante a ditadura; 2) legou o ônus da prova aos familiares; 3) não obrigou o Estado brasileiro à localizar os corpos dos desaparecidos; 4) excluiu a possibilidade de outros interessados ingressassem com o pedido de reconhecimento das mortes e/ou desaparecimentos, reforçando, com isso, a ideia de que os interessados são única e exclusivamente parentes das vítimas, algo que nega o caráter público da questão.

Apesar das críticas, o trabalho da $\mathrm{CEMDP}^{13}$ iniciou em janeiro de 1996. Composta por sete integrantes, a Comissão, que inicialmente funcionava junto ao Ministério da Justiça, desde 2003 funciona junto à Secretaria de Direitos Humanos da Presidência da República. A CEMDP começou suas atividades em ritmo intenso, visto que para protocolar os pedidos a serem analisados foi dado aos familiares um prazo exíguo: 120 dias, a contar do início das suas atividades. Apesar de não ser promovida pelo Governo ampla divulgação da Lei e do prazo para apresentar os pedidos junto à CEMDP, a mobilização dos familiares e da CFMDP possibilitou a apresentação de uma quantidade de novos casos maior do que era esperado pela nova Comissão, contando-se para tanto com a publicação de notícias em jornais de grande circulação (ALMEIDA et al., 2009, p. 34; BRASIL, 2007, p. 37-41; 2010, p. 135-136).

Nesse sentido, também foi fundamental à apresentação dos requerimentos dentro do prazo a mobilização da CFMDP. Nessa 
época (até maio de 1996), um escritório foi improvisado em Brasília, para auxiliar na elaboração dos pedidos de indenização. Para tanto, contou-se com o espaço cedido no gabinete e na residência do Deputado Federal Gilney Viana (PT/Mato Grosso). Lá, Suzana Lisbôa, Iara Xavier Pereira ${ }^{14}$, Criméia S. de Almeida ${ }^{15}$ e Maria Amélia Teles $^{16}$, dentre outros, trabalharam para que nenhum prazo não fosse perdido (ALMEIDA et al., 2009, p. 34; SANTOS, 2008, p. 142) .

Ademais, no início dos trabalhos da CEMDP, enfrentou-se outras duas dificuldades: 1) a presença do general Oswaldo Pereira Gomes como representante das Forças Armadas na Comissão, visto que seu nome havia figurado nos relatórios do Projeto Brasil: nunca mais como agente da repressão; 2) a falta de colaboração de órgãos oficiais na apresentação de documentos solicitados, já que, uma vez que não apresentados, dificultava a análise dos pedidos. Não fosse o empenho de familiares vasculhando os poucos arquivos disponíveis, muitos casos seriam indeferidos (ALMEIDA et al., 2009, p. 36-38; BRASIL, 2010, p. 135-137).

Nos anos que se seguiram ao início dos trabalhos da CEMDP, e, insatisfeitos com as limitações na Lei dos Mortos e Desaparecidos, os familiares lutaram pela sua revisão. As demandas para revisão da lei seriam em parte atendidas em 2002 e 2004. Em 2002, com a Lei $\mathrm{n}^{\circ} 10.536$, permitiu-se que o lapso temporal atingido pela Lei $\mathrm{n}^{\circ} 9.140$, que abrangia casos ocorridos entre 2 de setembro de 1961 e 15 de agosto de 1979, fosse estendido até o dia 5 de outubro de 1988 (promulgação da atual Constituição Federal). Posteriormente, buscando suprir dificuldades de interpretação e aplicação da Lei $n^{\circ}$ 9.140 surgidas nos julgamentos da CEMDP, familiares conseguiram com que fosse aprovada a Lei $\mathrm{n}^{\circ} 10.875$ de 2004. De acordo com essa lei, seriam reconhecidos pela CEMDP casos de pessoas: a) que foram mortas nas ruas, participando de passeatas ou de ações contra o regime; b) que cometeram suicídio ao receberem voz de prisão, ao terem sido presas e torturadas ou, ainda, devido a transtornos psíquicos resultantes da repressão (BRASIL, 2007, p. 44-46).

Até 2006 , em dez anos de apreciação dos 475 pedidos protocolados junto à CEMDP, foram reconhecidas como mortas e/ou desaparecidas, além das pessoas referidas no Anexo da Lei, outros 221 casos (BRASIL, 2007, p. 46-47). Em 2007, para documentar 
DO LUTO À LUTA: um estudo sobre a Comissão de Familiares...

e divulgar os resultados das suas atividades, a Comissão Especial lançou o livro-relatório Direito à Memória e à Verdade. O livro, de acordo com a CFMDP (ALMEIDA et al., 2009, p. 37):

[...] deixou claro que não podem coexistir versões conflitantes sobre as mortes. [...] O livro tem o sentido de complementar a indenização pecuniária estabelecida pela lei 9.140 e avançar na reparação ética e política. Representou grande vitória para os familiares de mortos e desaparecidos políticos, para os defensores dos direitos humanos e para todos os que desejam ver resgatada a memória do período ditatorial e avançar na construção da democracia no Brasil. O livro, enfim, em vez de virar essa página, contribui para imprimi-la na história do país.

Atualmente, a CEMDP dedica-se à organização de um banco de dados genéticos dos familiares para auxiliar na identificação dos restos mortais resgatados/a serem resgatados em valas clandestinas (BRASIL, 2007, p. 46-47; 2010, p. 136-138). Mas, além dos resultados obtidos com a Comissão Especial, vê-se que, a partir da segunda metade da década de 1990, os familiares obtiveram avanços em outros espaços ocupados em sua trajetória.

No que se relaciona à Vala de Perus, por exemplo, entre o final da década de 1990 e início dos anos 2000, obtiveram-se novos resultados. Em 1995, com o apoio do Secretário de Justiça de São Paulo, Belisário dos Santos Júnior, e da CEMDP, a CFMDP reuniu-se com o Reitor da UNICAMP, que substituiu o médico responsável pela pesquisa. Considerado insuficiente, o relatório do novo responsável, a partir de 1998, os familiares conseguiram: a) criar uma Comissão para tratar o tema, apoiados pela Secretaria de Justiça e da Cultura de São Paulo; b) transferir as ossadas para o Instituto Oscar Freire (DML da Universidade de São Paulo - USP); c) identificar duas ossadas (ALMEIDA et al., 2009, p. 26-28).

Dentre os espaços ocupados pelas demandas dos familiares, encontra-se ainda a arena do Poder Judiciário. Embora durante a repressão alguns familiares já tenham se dirigido à Justiça ${ }^{18}$, até meados da década de 1990, os esforços realizados na seara do Direito 
foram pouco exitosos à causa, prevalecendo, além das dificuldades de acesso aos arquivos da repressão (que limitava-limita a produção de provas) e da barreira da Lei da Anistia, a morosidade ${ }^{19}$ nos julgamentos (ALMEIDA TELES, 2010, p. 272-281).

Paradigmáticos no âmbito do Judiciário, no entanto, têm sido os desdobramentos da ação proposta em fevereiro de 1982 por familiares de 22 guerrilheiros desaparecidos na região do Araguaia, solicitando que o Estado brasileiro localizasse e trasladasse os corpos dos militantes, fornecesse os atestados de óbito (com a Lei $\mathrm{n}^{\circ}$ 9.140 esta demanda específica foi suprida) e apresentasse relatório produzido pelas Forças Armadas após o término das operações de liquidação da guerrilha. Em andamento até a atualidade, na fase de execução da sentença, a ação possibilitou ganhos importantes à causa em 2003, quando a Juíza da $1^{a}$ Vara da Justiça Federal do Distrito Federal reconheceu a legitimidade da demanda e condenou o Estado brasileiro a localizar os corpos de 70 desaparecidos e a apresentar os documentos requeridos (ALMEIDA et al., 2009, p. 38-43; ALMEIDA TELES, 2010, p. 284-294).

Paralelamente ao trâmite dessa ação no Judiciário brasileiro, como o andamento do processo marcava-se pela demora excessiva na fase de produção de provas, em 1995, os familiares dos desaparecidos peticionaram, junto à Comissão Interamericana de Direitos Humanos - COMIDH (vinculada à OEA), esperando, no plano internacional, obter as informações requeridas no Brasil. Após longo exame de admissibilidade, a petição foi aceita pela COMIDH em 2001. Em 2008, a COMIDH recomendou que o Brasil cumprisse a sentença da Justiça Federal do Distrito Federal, sob pena de, ao não cumpri-la, ter o caso repassado à Corte Interamericana de Direitos Humanos (CIDH), instância da OEA com poder jurisdicional (ALMEIDA TELES, 2010, p. 291-294).

Em abril de 2009, o caso foi repassado à CIDH. Na iminência de ser condenado internacionalmente por descumprir a legislação internacional de proteção aos direitos humanos, o Ministério da Defesa, chefiado por Nelson Jobim, criou um grupo de trabalhos para localizar os desaparecidos do Araguaia. Denominado Grupo de Trabalhos Tocantins (GTT), o grupo foi coordenado pelo Exército Brasileiro, não tendo sido integrados à equipe nenhum membro da 
DO LUTO À LUTA: um estudo sobre a Comissão de Familiares...

CEMDP, e, tampouco, dos familiares da CFMDP (BRASIL, 2010, p. 148-153). Em junho, apoiados pela Secretaria Especial de Direitos Humanos, a CEMDP e os familiares dos desaparecidos reuniram-se com o Ministro da Defesa e reclamaram sua participação nas buscas. O Ministro Nelson Jobim propôs que eles participassem como observadores ativos, o que foi rejeitado pela CFMDP (ALMEIDA TELES, 2010, p. 291). Em Carta Aberta ${ }^{20}$ dirigida ao presidente Lula, os familiares disseram:

Esperávamos não ser convidados como meros "observadores ativos" das "ações de âmbito militar" dentro de uma árdua luta que nós encabeçamos há tantos anos. Pelo contrário, esperávamos do Governo Federal e do Exmo. Senhor Presidente da República respeito por nossa luta, por nossa dor, por nosso luto inacabado e por nossos corpos insepultos. [...] É desesperador, depois de tantos anos, assistirmos passivamente o que ocorre, e ainda mais angustiante, saber que informações e pistas importantes sobre nossos familiares podem estar sendo destruídas, já que na coordenação do grupo de trabalho está um general de brigada, que declarou ao $O$ Norte de Minas sua defesa do golpe de 31 de março de $1964[\ldots]$.

Em julho, para minimizar a tensão, o presidente Lula (que nunca recebeu os familiares pesssoalmente) arbitrou o caso e criou um Comitê Interinstitucional de Supervisão dos Trabalhos, com integrantes da CEMDP e da CFMDP. Desde a sua criação, o GTT realizou 12 expedições de buscas, contando com a obtenção de informações junto aos moradores e ex-moradores da região e com o auxílio de ex-militares que participaram das operações (BRASIL, 2010, p. 148-153).

Em dezembro de 2010, os familiares obtiveram um ganho no plano internacional, quando foi julgado o caso encaminhado à CIDH em 2009 e o Brasil foi condenado a promover a busca dos corpos e a elucidar as circunstâncias das mortes dos militantes ${ }^{21}$. Em maio de 2011, com vistas ao início do cumprimento da sentença da $\mathrm{CIDH}$, além das disposições da decisão da $1^{\mathrm{a}}$ Vara da Justiça 
Federal do Distrito Federal de 2003, o GTT foi reestruturado e ampliado, numa parceria entre o Ministério da Defesa, o Ministério da Justiça e a Secretaria de Direitos Humanos. Denominado Grupo de Trabalho Araguaia, a equipe segue na busca dos desaparecidos (BRASIL, 2011a, p. 10).

Ainda dentre os avanços obtidos após a Lei no 9.140 , encontram-se ganhos concretizados: com a atuação-parceria da Comissão da Anistia (CA); com o projeto Memórias Reveladas (MR) e com a edição do PNDH-3.

A CA, vinculada ao Ministério da Justiça, foi criada em 2001 pelo presidente FHC, que regulamentou (na Medida Provisória convertida na Lei $n^{\circ} 10.559$ de 2002) o art. $8^{\circ}$ do Ato das Disposições Constitucionais Transitórias (ADCT) da Constituição Federal de 1988. De acordo com o art. $8^{\circ}$ do ADCT, foi prevista a criação de uma instância encarregada: a) de reconhecer a condição de anistiados políticos àqueles que, perseguidos por motivação política entre 1964 e 1988, lapso temporal que abrange o período autoritário, foram impedidos de exercer suas atividades e/ ou que perderam seus cargos em decorrência da edição de atos do Governo; b) de conceder-lhes sua respectiva reparação financeira (BRASIL, 2011b).

Alinhados aos princípios norteadores do conceito de justiça de transição difundido internacionalmente a partir da década de 1990 (GENRO, 2009), a divulgação desses trabalhos promove o resgate da memória da repressão em geral, algo que abrange a questão dos mortos e desaparecidos. Neste sentido, nas atividades da CA tem sido constantemente trabalhada publicamente por seus membros a questão do direito à memória e à verdade, e, além da realização das Caravanas da Anistia, sessões públicas de julgamento realizadas em todas as regiões do país desde 2007, em parceria com a Secretaria de Direitos Humanos da Presidência inauguraram-se 27 monumentos em memória dos mortos e desaparecidos, e, em parceria com a Universidade Federal de Minas Gerais, será construído um Memorial em Belo Horizonte ${ }^{22}$.

Em 2005, atendendo sugestão elaborada por um Grupo de Trabalhos coordenado pelo Ministro Paulo Vannuchi, que chefiou a Secretaria de Direitos Humanos de 2005 a 2010, começa a ser delineado o projeto Memórias Reveladas ${ }^{23}$. Lançado em 2009 e executado no 
DO LUTO À LUTA: um estudo sobre a Comissão de Familiares...

âmbito da Casa Civil da Presidência da República, na época chefiada pela Ministra-Chefe Dilma Rousseff, o projeto é coordenado pelo Arquivo Nacional, que custodia e disponibiliza os documentos do DOPS, do Conselho de Segurança Nacional, da Comissão Geral de Investigações e do Serviço Nacional de Informações.

Contando com uma plataforma on-line, o MR é, basicamente, uma base de dados destinada à pesquisa, obtenção, catalogação e disponibilização de documentos sobre a repressão. O projeto também visava, mediante propaganda televisiva veiculada no segundo semestre de 2009, a obter da população dados e informações que auxiliassem na elucidação das mortes e dos desaparecimentos ocorridos. Embora não fossem contrários à campanha pela arrecadação de documentos, que fazia com que a população conhecesse o tema, familiares criticaram o projeto ${ }^{24}$. De acordo com eles, era contraditório que o Governo transferisse o dever de contribuir à elucidação dos crimes da repressão à população, se, para tanto, bastava que o próprio Governo reformulasse sua política de sigilo. Embora mudanças na política de sigilo tenham sido aprovadas em 2011, dando fim ao sigilo eterno, e entrado em vigor recentemente (maio de 2012), não se verificam ainda, na prática, os efeitos da mudança ${ }^{25}$.

Visivelmente imbricada à demanda dos familiares por memória, verdade e justiça, encontra-se, finalmente, a organização da $3^{a}$ edição do PNDH, publicado pelo Governo Federal em dezembro de 2009. Concebido durante a Conferência Mundial sobre os Direitos Humanos, realizada em Viena, em 1993, o PNDH seria redigido para que cada país pudesse estabelecer uma agenda nacional com vistas à formulação de políticas para os direitos humanos, e, ao mesmo tempo, alinhá-la aos parâmetros internacionais estabelecidos na Conferência (GONZÁLEZ, 2010; KOERNER, 2003).

Em dezembro de 2008, as temáticas apresentadas na redação final do PNDH-3 ${ }^{26}$ foram discutidas publicamente em Brasília, durante a XI Conferência Nacional dos Direitos Humanos, tendo sido realizados, para subsidiá-la, debates em 137 conferências municipais, além de encontros estaduais em todos os Estados (IPEA, 2010, p. 284). Decorrente da participação dos familiares na elaboracão do PNDH-3, concretizou-se uma significativa ampliação do tratamento da memória da repressão, sendo reservado ao tema um Eixo 
específico do documento - Eixo VI -, intitulado Direito à memória e à verdade. Nele foram previstas, dentre outras: a) a preservação e promoção da memória da repressão (Diretriz no 24); b) a revisão da legislação que, produzida durante o período militar, ainda estava em vigor no país (Diretriz n $\left.{ }^{\circ} 25\right)$; c) de acordo com a Diretriz n ${ }^{\circ} 23$, a criação, em 2010, de uma Comissão Nacional da Verdade (CNV), a exemplo da Comissão da Verdade e Reconciliação que funcionou na África do Sul pós-apartheid, na segunda metade da década de 1990.

Tais medidas, que parcialmente atendiam as reivindicações que há anos eram realizadas pela CFMDP (ALMEIDA et al., 2009, p. 49-51) com o intuito de que fosse instalada no país uma Comissão da Verdade, mas também realizadora da Justiça, geraram discussões polêmicas. Neste sentido, quando foi lançado o PNDH-3 estamparam os jornais diversas manifestações e discussões envolvendo a crítica dos militares em torno do Eixo VI, bem como as divergências supostamente existentes entre os Ministros Nelson Jobim (da Defesa) e Paulo Vannuchi (dos Direitos Humanos) (GONZÁLEZ, 2010, p. 124-125).

No que se relaciona à questão dos mortos e desaparecidos, integrantes dos mesmos setores das Forças Armadas que, representados pelo Ministro da Defesa, haviam levado ao atraso na finalização do texto do PNDH-3 (IPEA, 2010, p. 285), influenciaram a opinião pública quando seria implementado o Plano. Como resultado, o Governo Federal recuou editando o Decreto n 7.177 (de maio de 2010), que alterou dispositivos do Eixo VI, de forma que a CNV, cujo foco inicialmente previsto centrava-se no período entre 1964 e 1985, fosse ampliado para o período entre 1946 e 1988.

Depois de reiteradas manifestações da presidenta Dilma Rousseff e da Ministra de Direitos Humanos, Maria do Rosário Nunes, a favor da aprovação do PL n ${ }^{\circ} 7.736$ de 2010, que criava a CNV, ainda no primeiro semestre de 2011, as votações na Câmara dos Deputados e do Senado foram finalizadas em setembro e outubro de 2011, sendo sancionada a Lei $\mathrm{n}^{\circ} 12.528$ em novembro. Aprovado pela Câmara abrangendo emendas propostas pelo DEM e pelo PSDB, o texto foi levado para votação no Senado com urgência urgentíssima, sendo aprovado sem novas emendas ${ }^{28}$. De acordo com o disposto nas emendas aprovadas pela Câmara no PL, decorreram limitações 
DO LUTO À LUTA: um estudo sobre a Comissão de Familiares...

à nomeação dos membros da Comissão, que não poderiam ser filiados a nenhum partido político.

Ao fazer um balanço da luta dos familiares, Criméia (BRASIL, 2010 , p. 66) chama a atenção para o fato de que, apesar de todos os esforços realizados, os desaparecidos continuam desaparecidos. Apesar do luto inacabado, convertido pela CFMDP em uma luta contínua por Memória, Verdade e Justiça, a atuação dos familiares pauta-se também na esperança de que a justiça, ausente no passado, ocorra. De acordo com Suzana Lisbôa ${ }^{29}$ :

Até hoje se aplaude quando os criminosos nazistas são condenados. Encontrados e condenados. É isso o que nós queremos que aconteça um dia. Que quando os torturadores brasileiros estejam julgados e condenados, nós possamos fazer com que o mundo venha aplaudir.

\section{Legados autoritários e sua repercussão na causa da CFMDP}

Repercutindo diretamente na organização dos familiares de mortos e desaparecidos políticos, o fim das mobilizações pela anistia e a desarticulação dos CBA's representou para este segmento não só o fim de um momento de luta compartilhada em torno de uma causa geral, mas também o início de sua reestruturação. É a partir de agosto de 1979, que, enfrentada a desmobilização dos seus membros, a CFMDP toma sua forma atual, constituindo-se como uma organização autônoma, composta por familiares e/ou pessoas próximas às vítimas fatais da repressão, engajados na luta pela elucidação das circunstâncias destes fatos, pela identificação e punição dos envolvidos e pelo resgate dos restos mortais.

Analisando a trajetória da CFMDP, identificam-se subjacentes à construção da causa, além dos percalços referidos, fragmentos daquilo que alguns estudiosos (HUGGINS, 2000; PEREIRA, 2010; STEPAN, 1988; ZAVERUCHA, 1992; 1994; 2005; 2010) referem 
como heranças ou legados autoritários, que, a despeito do fim da ditadura, projetam-se no tempo para além da duração do próprio regime. Observando-se o caso brasileiro, o legado que com bastante força se mantém até a atualidade é a interpretação que referenda a reciprocidade da anistia em benefício do esquecimento das violações ocorridas.

Referida como um dos itens não negociáveis da transição (MARTINS, 1988, p. 129), a garantia de não-responsabilização dos agentes da repressão se mantém arraigada no imaginário da população, sendo a tese da anistia recíproca reforçada em abril de 2010, pelo STF, quando a maioria dos Ministros negou provimento à $\mathrm{ADPF} \mathrm{n}^{\circ} 153$, proposta pelo Conselho Federal da OAB pedindo esclarecimentos sobre tal interpretação. Sustentando que a reconciliação nacional de 1979 justificava a impunidade dos agentes da repressão, o STF prejudica a discussão coletiva sobre as violações, subsidiando indiretamente a crença de que querer conhecer os fatos ocorridos naquele momento da história é revanchismo.

Num outro sentido, imbricada ao legado da anistia e bloqueando a efetivação do direito à memória e à verdade requerido pela CFMDP, verificou-se os efeitos da permanência de uma política nacional de sigilo documental, que até agora impediu e/ou dificultou o acesso à documentação oficial produzida no âmbito dos organismos responsáveis pela defesa da Segurança Nacional na ditadura. Afinal, ainda que, conforme referido na seção anterior, o fim do sigilo eterno tenha recentemente entrado em vigor, ainda não é possível encontrar resultados práticos das mudanças aprovadas. Além do que, é fato que enquanto esteve vigente, a política de sigilo constituiu um legado que tem produzido efeitos tanto individualmente como quando conjugada à interpretação da anistia.

De forma isolada, o sigilo impossibilitou a concretização do direito à memória e à verdade no plano coletivo, pois, já que muitos arquivos estiveram inacessíveis, as versões oficiais produzidas pelo regime continuarão carecendo de provas documentais que as revoguem publicamente. Conjugado à Lei de Anistia, o legado do sigilo surte efeitos no plano processual, uma vez que a prova documental produzida nos processos movidos por familiares das vítimas da repressão segue limitado aos poucos arquivos disponibilizados. 
DO LUTO À LUTA: um estudo sobre a Comissão de Familiares...

Por outro lado, verifica-se a presença de um legado autoritário também no âmbito das Forças Armadas, consolidado na existência e manutenção de uma série de prerrogativas militares (STEPAN, 1988; ZAVERUCHA, 1992; 1994; 2000; 2010) que estariam limitando as possibilidades de se democratizar as relações civis-militares. Isto porque, em linhas gerais, Jorge Zaverucha sustenta continuamente que, quanto maior o número de prerrogativas convivendo com sistemas democráticos, maior a possibilidade, na iminência de uma crise, que setores conservadores ensejem a intervenção direta de militares dispostos a usá-las. Somente em junho de 1999 a situação dessas prerrogativas no Brasil mudou um pouco, quando foi criado o Ministério da Defesa (ZAVERUCHA, 2000).

Se a existência de um mecanismo de controle civil mínimo pode ser vista como algo positivo (e, em certa medida, o é), no que tange aos resultados decorrentes do seu surgimento, no entanto, nota-se que o fato de existir um Ministro da Defesa, por si só, não necessariamente representa uma garantia de subordinação militar ao controle civil, atuando o mesmo mais como "[...] um despachante dos interesses das Forças Armadas do que um formulador de política governamental" (ZAVERUCHA, 2010, p. 70). Não é à toa que, atinente à memória da repressão e às demandas da CFMDP, encontra-se tanto no período pré-Ministério quanto após a sua criação, situações que relativizam análises mais otimistas sobre sua capacidade de produzir mudanças profundas no comportamento das Forças Armadas.

Conforme já foi visto, quando elaborava-se o PL da Lei $n^{\circ}$ 9.140, enfrentou-se resistência das Forças Armadas, sendo necessário que o próprio presidente garantisse que o reconhecimento das mortes e dos desaparecimentos dos militantes e a atuação da CEMDP não eram revanche, estando o alcance das medidas limitado à interpretação da anistia recíproca. Ainda assim, foi designado como representante das Forças Armadas na Comissão Especial o já referido general Oswaldo Pereira Gomes (BRASIL, 2010, p. 137), sendo a participação de militares constante, também, na coordenação das buscas no Araguaia.

Além dos legados autoritários contidos na interpretação da anistia, na politica nacional de sigilo e nas prerrogativas militares, identificam-se 
resquícios culturais do autoritarismo na atualidade. Neste sentido, o não enfrentamento dos traumas do passado, somado à impunidade que resguarda os autores dos crimes políticos, contribui à sedimentação de uma cultura em que o desrespeito aos direitos humanos é tido como algo natural, possibilitando que os responsáveis por práticas policiais violentas cometidas na atualidade vislumbrem, diante da impunidade da violência do passado, uma falta de constrangimentos para o seu uso indiscriminado no futuro (HUGGINS, 2000).

Comparado às experiências ditatoriais de países vizinhos como a Argentina (cerca de 30 mil pessoas) e o Chile (cerca de 5 mil pessoas), o saldo da repressão relativo aos mortos e desaparecidos políticos no Brasil é menos impactante. No Brasil foram identificados pela CFMDP, até a atualidade, 436 casos de mortes e/ou desaparecimentos políticos (ALMEIDA et al., 2009) - ver distribuição dos casos no Gráfico 1. De acordo com Anthony W. Pereira (2010), o que explicaria, em parte, o baixo número de vítimas fatais da repressão seria o tipo de legalidade autoritária constituída. Isto porque, segundo Pereira (2010, p. 53-63), no Brasil foi constituída uma legalidade autoritária que manteve em grande parte as estruturas legais pré-existentes. Assim, além de legitimar o combate aos opositores mediante Inquéritos Penais Militares, reduziu-se o espaço para a repressão extrajudicial. Assim, enquanto na Argentina, para cada pessoa julgada, houve 71 desaparecimentos, no Brasil, para cada morte ou desaparecimento, 23 pessoas foram julgadas pela Justiça Militar (PEREIRA, 2010, p. 59).

Ao observar o Gráfico 1, é possível fazer duas considerações sobre a repressão no Brasil. Primeiro, observando a distribuição dos casos de mortes e desaparecimentos pelo ano em que ocorreram, vê-se que estas violações estiveram presentes ao longo de todo o período ditatorial, estando suas maiores ocorrências situadas nos períodos em que a repressão foi mais dura: logo após o Golpe, na estabilização do regime e nos Anos de Chumbo (1969-1974). Constatado isto, observa-se que analisar o saldo referente às vítimas fatais do aparato repressivo de forma fragmentada e descontextualizada pode ter resultados perversos, servindo de fundamento àqueles que deslegitimam as demandas da CFMDP com base no número restrito de ocorrências registradas no Brasil (BAUER, 2011, p. 44-45). 
DO LUTO À LUTA: um estudo sobre a Comissão de Familiares...

Convém lembrar, portanto, que as violações ocorreram inseridas em uma lógica de ação repressiva alinhada à DSN (PADRÓS, 2006; 2008), em um contexto marcado: a) por cerca de 50 mil prisões nos primeiros meses após o golpe; b) por uma quantidade até hoje desconhecida de mortes em manifestações públicas; c) pela realização de inquéritos que atingiram mais de 10.000 pessoas; d) pela instauração de 707 processos na Justiça Militar, nos quais foram julgadas mais de 7.000 cidadãos; e) pela condenação de 4 pessoas à pena de morte (não consumada); f) pelo banimento de 130 militantes; g) pela cassação de 4.862 pessoas; h) por 6.592 militares atingidos por atos do regime ditatorial; i) por milhares de exilados e centenas de camponeses assassinados; j) pela expulsão de 245 estudantes universitários (ALMEIDA et al., 2009, p. 21; BRASIL, 2010, p. 12-13).

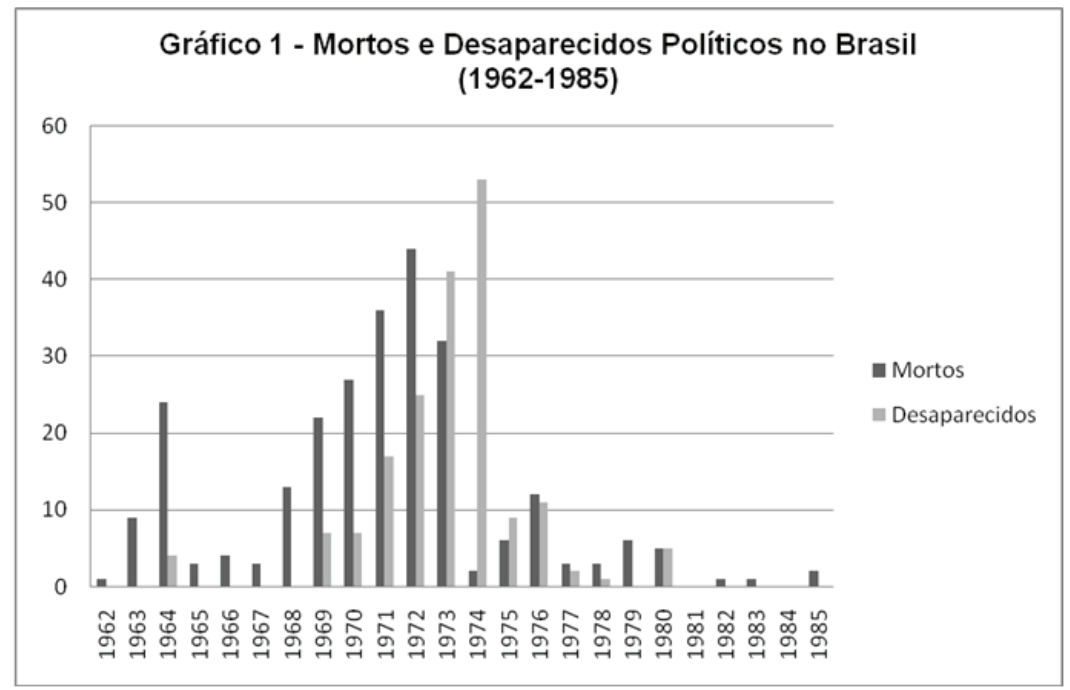

Fonte: Gráfico elaborado pelo autor com base em: ÁLMEIDA; et al., 2009. 


\section{Considerações finais}

As mortes e os desaparecimentos que sustentam as demandas formuladas e reformuladas ao longo das últimas décadas pela CFMDP constituem-se como uma das peças do quebra-cabeça deixado incompleto no processo de transição à democracia no Brasil. Ao trilharem um caminho frequentemente limitado pelos fragmentos de um legado autoritário que, a despeito do final do regime, projetase para o futuro reduzindo as possibilidades de recomposição de um passado traumático negligenciado, os familiares seguem, ano após ano, lutando para reduzir o hiato que foi estabelecido entre a memória e o esquecimento com o final da ditadura e sob a lógica da reconciliação nacional (MEZAROBBA, 2003).

Apesar dos percalços surgidos, as conquistas obtidas por essas famílias ao longo de sua trajetória, dentre as quais se destaca a Lei dos Mortos e Desaparecidos e a consequente concessão de reparações através dos trabalhos desenvolvidos pela CEMDP - embora não fosse este o foco dos familiares -, longe de poderem ser apontadas como os últimos atos das lutas travadas pelo restabelecimento da Verdade, pela Justiça e pela preservação da Memória daqueles que se opuseram ao regime civil-militar, podem ser observados como as bases necessárias à construção de outras conquistas, que, mais amplas e mais profundas, têm como desafio, ao enfrentarem o legado autoritário vigente no presente, promover o resgate da dimensão coletiva que a questão evidentemente abrange (BAUER, 2011, p. 317).

Respaldada pelo legado autoritário e induzida por políticas que privilegiam o esquecimento em detrimento da memória, a negação do caráter coletivo da questão torna o luto dos familiares de mortos e desaparecidos indefinidamente inconcluso (ALMEIDA TELES, 2009, p. 155-162), uma vez que consentir com o silêncio instituído permite "[...] a continuidade de um ato político de exceção" (TELES, 2009, p. 590). Enquanto não se consegue romper com esse legado, resgatar o passado, preservar a memória sobre o período, concluir o luto inacabado, e, finalmente, viver em uma realidade em que algo semelhante nunca mais aconteça, a luta dos familiares de mortos e desaparecidos continua. Afinal de contas, e como ensinam os próprios familiares, "[...] a única luta que se perde é aquela que se abandona". 


\section{FROM BEREAVEMENT TO THE FIGHT: A STUDY ABOUT THE COMMISSION OF THE FAMILIES OF THE DEAD AND DISAP- PEARED POLITICAL ACTIVISTS IN BRAZIL}

Abstract: This study examines the ways in which relatives of people killed or disappeared during the civil-military dictatorship in Brazil (1964-1985) were organized to demand: 1) recognition of liability by the Brazilian state for violations of human rights committed;2) the investigation of actual circumstances of these deaths and disappearances; 3) liability of perpetrators; 4) the rescue and preservation of the memory on these facts. Strengthened in the first half of the 1970s, the struggle of families organized around the Commission of the Families of the Dead and Disappeared Political Activists (CFDDPA) extends until present. In more than three decades, CFDDPA work persistently to the society in an attempt to make the crimes committed during authoritarian period are not forgotten and seeking to extend their support towards the construction of policies that meet their demands. The Commission continues, however, dealing with legacies of authoritarian regimes, that still follow limiting the obtaining of significant advances with regard to compensation to the families.

Keywords: Civil-Military Dictatorship in Brazil (1964-1985). Commission of the Families of the Dead and Disappeared Political Activists. Human Rights. Legacies of Authoritarism. Memory on the Political Repression.

\section{Notas}

${ }^{1}$ Neste artigo são apresentados dados e discussões abrangidas originalmente em minha dissertação de mestrado, defendida no Programa de Pós-Graduação em Ciência Política da UFRGS, em março de 2012. A pesquisa que deu origem à dissertação foi realizada com auxílio financeiro do CNPq.

${ }^{2}$ Embora o uso das expressões desaparição forçada, desaparecimentos e desaparecidos tenha adquirido novos contornos no cenário internacional a partir das experiências repressivas vivenciadas na Guatemala, no Chile e na Argentina (AMNISTÍA INTERNACIONAL, 1983, p. 7-8), tais situações não são uma novidade criada pelas ditaduras latino-americanas. Neste sentido, as origens do desaparecimento de opositores civis como uma política repressiva específica de um Estado autoritário podem ser encontradas na doutrina contrarrevolucionária francesa, na Alemanha nazista e na Espanha franquista (PADRÓS, 2005, p. 613-614).

${ }^{3}$ Quanto às nomenclaturas mortos e desaparecidos utilizadas pelos familiares: o termo desaparecidos designa aqueles que, até a edição da Lei nº 9.140/95, não haviam sido publicamente declarados mortos pela repressão e que, ainda sem Registro 
de Óbito, tiveram o cadáver ocultado; a expressão mortos, por sua vez, abrange casos em que foi elaborada (por integrantes do regime) uma versão oficial sobre as mortes, mesmo que subsista até a atualidade, semelhante ao primeiro grupo, a ocultação dos cadáveres (ALMEIDA et al. 2009, p. 22).

${ }^{4}$ Suzana Keniger Lisbôa foi militante da Ação Libertadora Nacional (ALN). Nascida em Porto Alegre em 1951, casou, em março de 1969, com Luiz Eurico Tejera Lisbôa, militante da ALN desaparecido em setembro de 1972, em São Paulo. Em março de 1979, Suzana descobriu o corpo de Luiz Eurico enterrado com nome falso (Nelson Bueno), no Cemitério de Perus (São Paulo). Engajada na luta pela proteção aos direitos humanos e pela causa dos familiares de mortos e desaparecidos, desde o final da década de 1970, Suzana ganhou destaque nacional e internacional, trabalhou, de 1994 a 2010, na Comissão de Cidadania e Direitos Humanos da Assembleia Legislativa do Estado do Rio Grande do Sul e, de 1995 a 2005, fez parte da CEMDP.

${ }^{5}$ Entrevista com Suzana Keniger Lisbôa, Porto Alegre, 16 de junho de 2011.

${ }^{6}$ Entrevista com Suzana Keniger Lisbôa, Porto Alegre, 16 de junho de 2011.

${ }^{7}$ Para mais informações, ver: <http://www.desaparecidos.org/fedefam>. Acesso em: 01 ago. 2011.

${ }^{8}$ Entrevista com Suzana Keniger Lisbôa, Porto Alegre, 16 de junho de 2011.

${ }^{9}$ Entrevista com Suzana Keniger Lisbôa, Porto Alegre, 16 de junho de 2011.

${ }^{10}$ Entrevista com Suzana Keniger Lisbôa, Porto Alegre, 16 de junho de 2011.

${ }^{11}$ Teotônio Vilela (1917-1983) foi um político brasileiro. Filiado à União Democrática Nacional (UDN), quando instaurado o bipartidarismo no Brasil, em 1965, filiou-se ao partido da ditadura, a Aliança Renovadora Nacional (ARENA). Na transição, destacou-se como dissidente do Governo e fazia oposição interna ao regime. Suzana Lisbôa (na entrevista de 16 de junho de 2011) relatou que o apoio de Teotônio Vilela aos familiares foi imenso no período da transição e, sobretudo, após a Anistia. Além de ter acesso à sua casa sempre que solicitado, Suzana disse que o Senador fornecia passagens aéreas da sua cota pessoal para familiares irem a Brasília reivindicar.

${ }^{12}$ O Deputado Federal Jair Bolsonaro já ganhou destaque na opinião pública brasileira ao se envolver em discussões polêmicas (manifestando-se contra o sistema de cotas raciais nas Universidades, ironizando a situação dos povos indígenas, fazendo apologia ao preconceito contra homossexuais e em defesa da tortura, dentre outras temáticas). É filiado ao atual Partido Progressista (PP), herdeiro político da ARENA.

${ }^{13}$ Uma análise detalhada sobre a primeira fase de trabalhos da CEMDP encontrase em: SANTOS, 2008.

${ }^{14}$ Iara Xavier Pereira é viúva de Arnaldo Cardoso Rocha e irmã de Alex e Iuri Xavier Pereira, todos mortos pela repressão.

Anos 90, Porto Alegre, v. 19, n. 35, p. 329-361, jul. 2012 
${ }^{15}$ Criméia Alice Schmidt de Almeida fez parte da Guerrilha do Araguaia, operação de guerrilha rural organizada pelo Partido Comunista do Brasil (PCdoB) na região amazônica do Rio Araguaia (localizada, à época, entre os Estados de Goiás, Pará e Maranhão, e atualmente na região norte de Tocantins) do final da década de 1960 até 1974 . Sendo uma das poucas pessoas sobreviventes da guerrilha, Criméia teve um relacionamento amoroso com André Grabois, Comandante do Destacamento A da Guerrilha do Araguaia desaparecido em outubro de 1973. Grávida de André, e enfrentando dificuldades durante a gestação, Criméia afastou-se da região para realizar missão do partido, passando a viver clandestinamente em São Paulo a partir de 1972. Destacando-se na sua atuação junto à CFMDP desde a década de 1970, Criméia, que também teve o sogro (o dirigente comunista Mauricio Grabois) desaparecido na região do Araguaia, foi presa, e, mesmo grávida, torturada, tendo seu filho nascido no Hospital Militar de Brasília, onde ela ficou detida.

${ }^{16}$ Maria Amélia da Silva Teles é integrante da CFMDP, embora não tenha vínculo direto com nenhum dos mortos e desaparecidos políticos no Brasil. Durante a ditadura, ela e seu marido, César Teles, foram militantes do PCdoB. Presos e torturados conjuntamente, Maria Amélia e César tiveram seus filhos, Janaína e Edson, respectivamente com 5 e 4 anos de idade, detidos. No DOPS, as crianças viram os pais com as marcas de tortura e, depois, foram levadas para a casa de um delegado que ameaçava ficar com as crianças.

${ }^{17}$ Entrevista com Suzana Keniger Lisbôa, Porto Alegre, 16 de junho de 2011.

${ }^{18}$ Conforme levantamento de Criméia Schmidt de Almeida (et al., 2009, p. 45-46) e Janaína de Almeida Teles (2010, p. 272-281), ações com vistas à responsabilização do Estado brasileiro pela morte ou pelo desaparecimento de opositores do regime civil-militar foram propostas por familiares de Manoel Raymundo Soares (morto em 1966), Mário Alves de Souza Vieira (desaparecido em 1970), Raul Amaro Nin Ferreira (morto em 1971), Rubens Beirodt Paiva (desaparecido em 1971), Luiz Eurico Tejera Lisbôa (desaparecido em 1972), Vladimir Herzog (morto em 1975), Manoel Fiel Filho (morto em 1976) e Santo Dias da Silva (morto em 1979). ${ }^{19}$ Em processo iniciado em 1973 por dona Elizabeth Challup Soares na Justiça Federal de Porto Alegre, por exemplo, foi reconhecida a responsabilidade estatal pela tortura e morte de seu marido e concedida indenização por danos materiais. Ocorre, contudo, que até ser julgado, em 2000, há uma espera de 27 anos, e, durante a execução da sentença, que segue tramitando, dona Elizabeth faleceu (ALMEIDA TELES, 2010, p. 272-275).

${ }^{20}$ Disponível em: <http://www.desaparecidospoliticos.org.br/pagina. php?id $=259 \& \mathrm{~m}=6>$.

${ }^{21}$ A sentença do Caso Guerrilha do Araguaia proferida pela CIDH pode ser consultada em: <http://www.corteidh.or.cr/docs/casos/articulos/seriec_219_por. pdf $>$. Cabe recordar que, em abril de 2010, o STF decidiu, ao julgar a ADPF 
$n^{\circ} 153$ proposta pelo Conselho Federal da OAB, que a interpretação da Lei da Anistia difundida desde a sua publicação deve ser mantida. Diante disso, tem-se, no plano internacional, uma decisão que afirma que a Lei brasileira não anistiou os agentes da repressão, mas, em âmbito interno, uma decisão que sustenta que a anistia foi recíproca. Por enquanto, como a decisão da CIDH foi publicada recentemente, em junho de 2011, os desdobramentos jurídicos do cumprimento de ambas as sentenças (que visivelmente apontam para caminhos opostos) ainda não foram objeto de ampla discussão.

${ }^{22}$ Para mais informações, consultar: <http://www.mj.gov.br/anistia $>$.

${ }^{23}$ Para maiores detalhes, ver: <http://www.memoriasreveladas.arquivonacional. gov.br>.

${ }^{24}$ Conforme reportagem do jornal Zero Hora de $1^{\circ}$ de novembro de 2009 (Referências).

${ }^{25}$ As votações do Projeto de Lei da Câmara no 41/2010, que trata sobre o sigilo de documentos e que modifica a política de acesso às informações no país tramitou no Congresso Nacional desde 2010.

${ }^{26}$ Disponível em: <http://portal.mj.gov.br/sedh/pndh3/pndh3.pdf>.

${ }^{27}$ Os meios de comunicação deram ampla cobertura às polêmicas surgidas em torno do lançamento do PNDH-3. No jornal Zero Hora, por exemplo, no período que vai de 9 a 15 de janeiro de 2010 (Referências), auge das polêmicas, diversas reportagens e editoriais deram destaque às discussões.

${ }^{28}$ Manifestações da presidenta Dilma e da Ministra Maria do Rosário pela aprovação do PL n 7.736 foram, com frequência, divulgadas nos sites da Secretaria de Direitos Humanos e do projeto Memórias Reveladas.

${ }^{29}$ Depoimento de Suzana Keniger Lisbôa. Disponível na videoteca digital do NEV/USP em: <NEVUSP-ConferenciaDireitoAVerdade19SuzanaLisboa286. wmv>.

\section{Referências}

A CONSTRUÇÃO da verdade histórica (Editorial). Jornal Zero Hora, Porto Alegre, 11 jan. 2010, p. 12.

ALMEIDA, Criméia Schmidt de et al. Dossiê ditadura: mortos e desaparecidos políticos no Brasil (1964-1985). 2. ed. rev., ampl. e atual. São Paulo: Imprensa Oficial do Estado de São Paulo, 2009.

ALMEIDA TELES, Janaína de. Mortos e desaparecidos políticos: um resgate da memória brasileira. In: (Org.). Mortos e desaparecidos políticos: reparação ou impunidade? 2. ed. São Paulo: Humanitas/FFLCH/USP. 2001. p. 157-198. 
DO LUTO À LUTA: um estudo sobre a Comissão de Familiares...

Entre o luto e a melancolia: a luta dos familiares de mortos e desaparecidos no Brasil. In: SANTOS, Cecília MacDowell; TELES, Edson; (Org.). Desarquivando a ditadura: memória e justiça no Brasil. v. 1. São Paulo: HUCITEC. 2009. p. 151-176.

. Os familiares de mortos e desaparecidos políticos e a luta por "verdade e justiça" no Brasil. In: TELES, Edson; SAFATLE, Vladimir (Org.). O que resta da ditadura: a exceção brasileira. São Paulo: Boitempo. 2010. p. 253-298.

ALVES, Maria Helena Moreira. Estado e oposição no Brasil (1964-1984). Bauru: Edusc, 2005.

AMNISTÍA INTERNACIONAL. Desapariciones. Madrid: Editorial Fundamentos, 1983.

. Crimenes sin castigo. Madrid: EDAI, 1993.

ARQUIDIOCESE DE SÃO PAULO. Brasil: nunca mais. 4. ed. Petrópolis: Vozes, 1985.

ARTURI, Carlos Schmidt. O debate teórico sobre mudança de regime político: o caso brasileiro. Revista de Sociologia e Política, Curitiba, n.17, p. 11-31, nov. 2001.

AS "CRISES" e os direitos humanos (Editorial). Jornal Zero Hora, Porto Alegre, 12 jan. 2010, p. 15.

BAUER, Caroline Silveira. Um estudo comparativo das práticas de desaparecimento nas ditaduras civil-militares argentina e brasileira e a elaboração de politicas de memória em ambos os países. 445f. [2v.]. Tese (Doutorado em História) - Programa de Pós-Graduação em História da Universidade Federal do Rio Grande do Sul. Porto Alegre/Departament d'Història Contemporània da Universitat de Barcelona, Barcelona. 2001.

BRASIL. Secretaria Especial de Direitos Humanos. Comissão Especial sobre Mortos e Desaparecidos Políticos. Direito à memória e direito à verdade. Brasília: SEDH, 2007.

Secretaria de Direitos Humanos. Habeas Corpus: que se apresente o corpo: a busca dos desaparecidos políticos no Brasil. Brasília: SDH, 2010.

. Secretaria de Direitos Humanos. Direitos Humanos pelo Brasil: o trabalho da Secretaria de Direitos Humanos da Presidência da República para a afirmação e defesa dos direitos de todos os brasileiros e brasileiras. Brasília: SDH, 2011a.

. Ministério da Justiça; Comissão de Anistia. Cartilha Informativa da Comissão de Anistia. 2. ed. Brasília: CA/MJ, 2011b.

CAMPANHA irrita familiares. Jornal Zero Hora, Porto Alegre, $1^{\circ}$ nov. 2009, p. 6.

Anos 90, Porto Alegre, v. 19, n. 35, p. 329-361, jul. 2012 


\section{Carlos Artur Gallo}

CARVALHO, José Murilo de. Cidadania no Brasil: o longo caminho. 13. ed. Rio de Janeiro: Civilização Brasileira, 2010.

CATELA, Ludmila da Silva. Situação-limite e memória: a reconstrução do mundo dos familiares de desaparecidos da Argentina. São Paulo: HUCITEC/ANPOCS, 2001.

DIREITO à memória e à verdade (Editorial). Jornal Zero Hora, Porto Alegre, 12 jan. 2010, p. 15.

GENRO, Tarso. Teoria da Democracia e Justiça de Transição. Belo Horizonte: Editora UFMG, 2009.

GONZÁLEZ, Rodrigo Stumpf. A política de promoção aos direitos humanos no Governo Lula. Revista Debates, Porto Alegre, v. 4, n. 2, p. 107-135, 2010.

GRUPOS de direitos humanos defendem saída de Jobim. Jornal Zero Hora, Porto Alegre, 15 jan. 2010, p. 29.

HUGGINS, Martha K. Legacies of authoritarianism: Brazilian torturers' and murderers' reformulation of memory. Latin American Perspectives, Thousand Oaks/ London/New Delhi, v. 27, n. 2, p. 57-78, 2000.

HUNTINGTON, Samuel P. A terceira onda. São Paulo: Ática, 1994.

IPEA. Direitos Humanos e Cidadania. In: Políticas sociais: acompanhamento e análise. Brasília: IPEA. p. 283-305, 2010.

KOERNER, Andrei. O papel dos direitos humanos na política democrática: uma análise preliminar. Revista Brasileira de Ciências Sociais, v. 18, n. 53, p. 143-157, 2003.

LULA tende a desidratar programa. Jornal Zero Hora, Porto Alegre, 12 jan. 2010, p. 6.

LULA vai reeditar plano para contornar crise. Jornal Zero Hora, Porto Alegre, 13 jan. 2010, p. 12.

MARTINS, Luciano. A "liberalização" do regime autoritário no Brasil. In: O’DONNELL, Guillermo; SCHMITTER, Philippe C.; WHITEHEAD, Laurence (Org.). Transições do regime autoritário: América Latina. São Paulo: Vértice/ RT. 1988, p. 108-139.

MARTINS, Roberto Ribeiro. Liberdade para os brasileiros: anistia ontem e hoje. 2. ed. Rio de Janeiro: Civilização Brasileira, 1978.

MEZAROBBA, Glenda. Um acerto de contas com o futuro: a anistia e suas consequências: um estudo do caso brasileiro. 213f. Dissertação (Mestrado em Ciência Política) - Programa de Pós-Graduação em Ciência Política da Universidade de São Paulo, São Paulo, 2003. 
MOTTA, Rodrigo Patto Sá. Em guarda contra o perigo vermelho: o anticomunismo no Brasil (1917-1964). São Paulo: Perspectiva/Fapesp, 2002.

ONU. Desapariciones forzadas o involuntarias. Genebra: United Nations, 1993.

PADRÓS, Enrique Serra. Como el Uruguay, no hay... Terror de Estado e Segurança Nacional Uruguai (1968-1985): do pachecato à ditadura civil-militar. 874f. [2v.]. Tese (Doutorado em História) - Programa de Pós-Graduação em História da Universidade Federal do Rio Grande do Sul, Porto Alegre, 2005.

. Elementos constitutivos do Terror de Estado implementado pelas Ditaduras Civis-Militares de Segurança Nacional latino-americanas. In:

(Org.). As ditaduras de Segurança Nacional: Brasil e Cone Sul. Porto Alegre: Corag. 2006, p. 15-22.

. Repressão e violência: segurança nacional e terror de Estado nas ditaduras latino-americanas. In: FICO, Carlos et al. (Org.). Ditadura e democracia na América Latina: balanço histórico e perspectivas. Rio de Janeiro: FGV, 2008, p. 143-178.

PEREIRA, Anthony W. Ditadura e repressão: o autoritarismo e o estado de direito no Brasil, no Chile e na Argentina. Rio de Janeiro: Paz e Terra, 2010.

PLANO de direitos humanos provoca onda de protestos. Jornal Zero Hora, Porto Alegre, 9 jan. 2010, p. 6.

PLANO funesto (Editorial). Jornal Zero Hora, Porto Alegre, 11 jan. 2010, p. 13.

PRADO, Larissa Brisola Brito. Estado democrático e políticas de reparação no Brasil: tortura, desaparecimentos e mortes no regime militar. 209f. Dissertação (Mestrado em Ciência Política). Departamento de Ciência Política do Instituto de Filosofia e Ciências Humanas da Universidade Estadual de Campinas, Campinas, 2004.

RACHA no governo faz presidente rever plano. Jornal Zero Hora, Porto Alegre, 11 jan. 2010, p. 6.

REIS, Daniel Aarão; RIDENTI, Marcelo; MOTTTA, Rodrigo Patto Sá. Introdução. In:__ (Org.). O golpe e a ditadura militar: quarenta anos depois (1964-2004). Bauru: Edusc, 2004. p. 9-11.

SANTOS, Sheila Cristina. A Comissão Especial sobre Mortos e Desaparecidos Politicos e a reparação do Estado às vítimas da ditadura militar no Brasil. 247f. Dissertação (Mestrado em Ciências Sociais). Programa de Estudos Pós-Graduados em Ciências Sociais da Pontifícia Universidade Católica de São Paulo, São Paulo. 2008.

SOB pressão, Lula altera plano de direitos humanos. Jornal Zero Hora, Porto Alegre, 14 jan. 2010, p. 28.

Anos 90, Porto Alegre, v. 19, n. 35, p. 329-361, jul. 2012 


\section{Carlos Artur Gallo}

STEPAN, Alfred. As prerrogativas militares nos regimes pós-autoritários: Brasil, Argentina, Uruguai e Espanha. In: (Org.). Democratizando o Brasil. Rio de Janeiro: Paz e Terra, 1988. p. 521-562.

TELES, Edson Luís de Almeida. Brasile África do Sul: os paradoxos da democracia: memória política em democracias com herança autoritária. 152f. Tese (Doutorado em Filosofia). Programa de Pós-Graduação em Filosofia da Universidade de São Paulo, São Paulo, 2007.

. Brasil e África do Sul: rupturas e continuidades nas transições políticas. In: SOARES, Inês Virgínia do Prado; KISHI, Sandra Akemi Shimada (Coord.). Memória e verdade: a justiça de transição no estado democrático brasileiro. Belo Horizonte: Fórum, 2009a. p. 119-131.

Políticas do silêncio e interditos da memória na transição do consenso. In: SANTOS, Cecília MacDowell; ___ _ TELES, Janaína de Almeida (Org.). Desarquivando a ditadura: memória e justiça no Brasil. v. 2. São Paulo: HUCITEC. 2009b. p. 578-591.

. Entre justiça e violência: estado de exceção nas democracias do Brasil e da África do Sul. In: ; SAFATLE, Vladimir (Org.). O que resta da ditadura: a exceção brasileira. São Paulo: Boitempo, 2010. p. 299-318.

ZAVERUCHA, Jorge. Prerrogativas militares nas transições brasileira, argentina e espanhola. Revista Brasileira de Ciências Sociais, n. 19, 1992, p. 56-65.

. Rumor de sabres. São Paulo: Ática, 1994.

. Frágil democracia: Collor, Itamar, FHC e os militares (1990-1998). Rio de

Janeiro: Civilização Brasileira, 2000.

. FHC, forças armadas e polícia: entre o autoritarismo e a democracia (19992002). Rio de Janeiro: Record, 2005.

- Relações civil-militares: o legado autoritário da Constituição brasileira de 1988. In: TELES, Edson; SAFATLE, Vladimir (Org.). O que resta da ditadura: a exceção brasileira. São Paulo: Boitempo, 2010, p. 41-76.

Recebido em: 28/05/2012

Aprovado em: 11/09/2012 